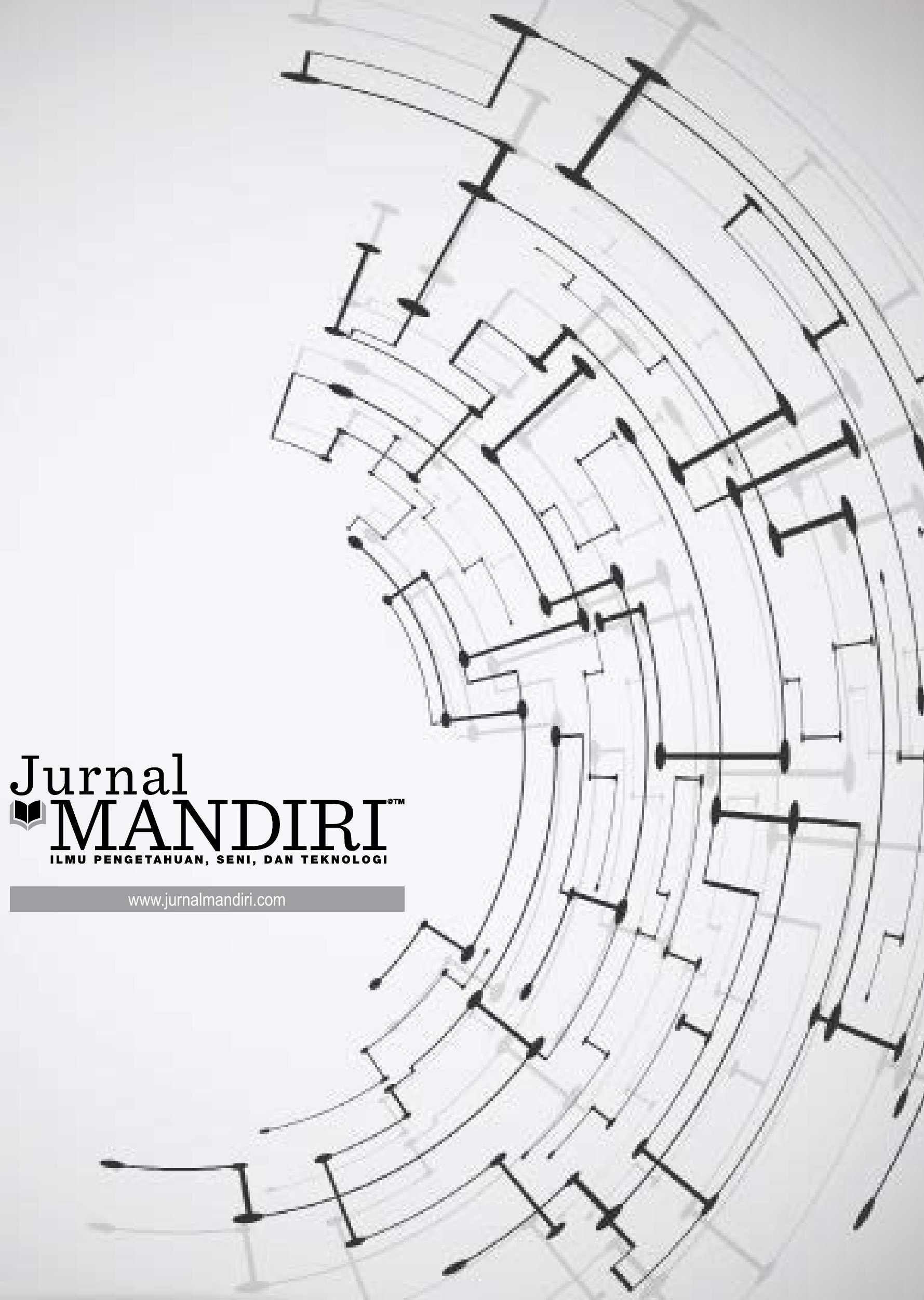


ISSN : 2580-3220, E-ISSN : 2580-4588

J. Mandiri., Vol. 1, No. 1, Juni 2017 (69 - 83)

(C)2017 Lembaga Kajian Demokrasi

dan Pemberdayaan Masyarakat (LKD-PM)

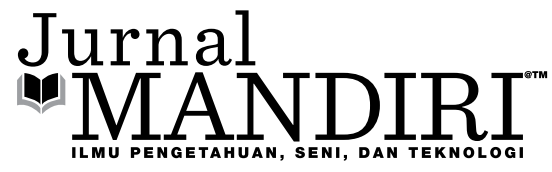

\title{
PENGEMBANGAN MODEL KERJA SAMA LINK AND MATCH \\ UNTUK MENINGKATKAN KESIAPAN KERJA BAGI LULUSAN \\ SMK KOMPETENSI KEAHLIAN AKUNTANSI \\ DI KOTA SEMARANG
}

\author{
Ivan Putranto \\ Fakultas Ekonomi, Universitas Pamulang \\ e-mail: ivanputranto21@gmail.com
}

\begin{abstract}
ABSTRAK
Penelitian ini bertujuan untuk (1) mengembangkan model kerja sama link and match untuk meningkatkan kesiapan kerja bagi lulusan SMK Kompetensi Keahlian Akuntansi di Kota Semarang, (2) mengetahui model kerja sama link and match yang efektif untuk diterapkan guna meningkatkan kesiapan kerja bagi lulusan SMK Kompetensi Keahlian Akuntansi di Kota Semarang. Jenis penelitian ini adalah Research and Development (R\&D). Lokasi penelitian ini dilakukan di SMK Negeri 9 Semarang, SMK LPI, dan SMK Perintis 29-01 Jurusan Bisnis Manajemen Kompetensi Keahlian Akuntansi dan Dunia Usaha Dunia Industri (DUDI) pasangan. Penetapan informan sebagai sumber data menggunakan teknik purposive sampling. Pengumpulan data menggunakan teknik wawancara mendalam, observasi, dokumentasi dan angket. Penelitian ini menggunakan metode kualitatif dan kuantitatif. Metode kualitatif dilakukan dengan wawancara mendalam, observasi dan dokumentasi untuk mengembangkan model kerja sama link and match untuk meningkatkan kesiapan kerja, sedangkan metode kuantitatif dilakukan dengan pengisian angket untuk analisis kebutuhan penelitian. Keabsahan data diperoleh melalui credibility, transferability, dependability, dan confirmatory. Analisi data kualitatif: reduksi data, paparan data, dan penarikan kesimpulan data dan verifikasi, kuantitatif: validitas dan reliabilitas. Hasil penelitian menunjukkan bahwa (1) pengembangan model kerja sama link and match untuk meningkatkan kesiapan kerja dilakukan dengan menambahkan komponen sosialisasi kompetensi siswa, keterlibatan DUDI dalam penerimaan siswa baru dan identifikasi kompetensi kebutuhan oleh DUDI (2) model kerja sama link and match dikatakan efektif bilamana model kerja sama link and match mengantarkan standar kompetensi lulusan SMK sama dengan kompetensi harapan DUDI.
\end{abstract}

Kata Kunci: Link and Match, Kesiapan Kerja, Kompetensi Keahlian Akuntansi.

\section{PENDAHULUAN}

Pertautan antara dunia pendidikan dan dunia industri yang sering disebut link and match masih bermasalah. Upaya menjaga relevansi antara pendidikan dan industri tidak tepat jika hanya dimaknai sekedar mentransfer teknologi dan ketrampilan khas yang digunakan dunia industri ke lembaga pendidikan. Link and match harus dimaknai sebagai upaya lembaga pendidikan dalam menyiapkan orang- 
orang yang mempunyai kemampuan berpikir, berkomunikasi, berinteraksi sosial, dan bekerja dalam tim.

Konsep link and match dalam dunia pendidikan dikenalkan oleh Prof. Dr. Ing. Wardiman Djojonegoro sewaktu menjabat menjadi Menteri Pendidikan dan Kebudayaan yang mana konsep tersebut mengacu pada keterkaitan (link) dan kesesuaian (match) antara dunia pendidikan dan Dunia Usaha Dunia Industri (DUDI) (Djojonegoro 2007: 1 dan Judissuseno, 2008: 14). Maksud keterkaitan (link) dan kesesuaian (match) adalah kompetensi lulusan dari dunia pendidikan dapat diterima dan cocok dengan kebutuhan dunia kerja. Perspektif link menunjukkan proses, yang berarti bahwa proses pendidikan selayaknya sesuai dengan kebutuhan pembangunan, sehingga hasilnya pun cocok (match) dengan kebutuhan tersebut, baik dari segi jumlah, mutu, jenis, kualifikasi maupun dari segi waktunya. Beberapa prinsip yang akan dipakai dalam strategi dalam kebijakan link and match diantaranya adalah model penyelenggaraan Pendidikan Sistem Ganda (PSG).

Sekolah Menengah Kejuruan yang diharapkan dapat menjadi jembatan link and match karena memiliki dual system education ternyata juga belum memenuhi harapan. Masih banyak lulusan SMK yang belum terserap dunia kerja. Tidak terserapnya lulusan SMK tersebut bukan mutlak karena tidak adanya lapangan kerja, tetapi karena rendahnya kompetensi lulusan. Banyak lowongan kerja yang tersedia tidak terisi karena pelamar tidak memenuhi kriteria pemberi kerja. Hal ini sebenarnya lapangan kerja tersedia, tetapi peminat tidak memenuhi persyaratan kompetensi yang diminta. Banyak ditemukan diantara lulusan yang bekerja, tidak sesuai dengan bidang kompetensi yang siswa pelajari. Beberapa perusahaan yang masih peduli dan memanfaatkan lulusan SMK, sebagian besar menempatkan lulusan SMK bekerja di pos yang tidak sesuai jurusan, contohnya menjadi satpam, penjaga toko atau tempat bermain anak.

Menurut Wibowo (2008: 1) ada beberapa hal yang menyebabkan ketidaksesuaian (mismatch) antara SMK dengan dunia usaha. Pertama, tidak semua SMK mencetak lulusan yang adaptif dengan dunia kerja, hal ini dikarenakan ketidaktersediaan fasilitas bengkel atau laboratorium kerja (workshop) yang layak dan modern, serta membangun kerja sama yang kuat dengan dunia kerja. Kedua, dari aspek tenaga pengajar banyak guru SMK yang ketinggalan meng-update keahlian agar sesuai dengan perkembangan zaman, akibatnya banyak pendidikan di SMK yang dilaksanakan secara asal-asalan, sehingga muaranya hanya menghasilkan lulusan tanpa kompetensi yang memadai. Ketiga, program yang ditawarkan SMK saat ini belum efektif dan efisien.

Permasalahan ketidaksesuaian (mismatch) kompetensi antara DUDI dengan kompetensi lulusan tidak mutlak kesalahan pihak dunia pendidikan. Pihak DUDI sendiri tidak mampu mengantisipasi kompetensi yang bakal muncul dan diharapkan di masa depan. Pemberian informasi kebutuhan kompetensi oleh DUDI pada sekolah didasarkan kompetensi yang dibutuhkan sekarang, artinya perbedaan waktu membuat identifikasi kompetensi menjadi tidak up to date lagi. Adanya mismatch tersebut menjadi salah satu hal yang menyebabkan pengangguran, karena kompetensi yang diinginkan oleh dunia industri tidak sesuai dengan kompetensi yang dimiliki oleh lulusan SMK.

Masalah pengangguran sendiri bukan menjadi masalah yang baru di Indonesia, dari tahun ke tahun masalah pengangguran masih menjadi masalah yang harus diselesaikan oleh semua kalangan. Penyebabnya pun beraneka ragam, selain kurangnya lapangan pekerjaan, rendahnya kompetensi keahlian yang dimiliki sehingga susah untuk terjun langsung ke lapangan pekerjaan, tidak memenuhi kriteria yang ditentukan oleh perusahaan tertentu, ketidaksesuaian mismatch antara kompetensi lulusan dengan kompetensi yang diinginkan oleh pemberi kerja juga merupakan hal yang menjadi faktor utama yang menyebabkan pengangguran. 


\begin{tabular}{|c|c|c|c|c|}
\hline \multicolumn{5}{|l|}{ Tabel } \\
\hline No. & Pendidikan yang ditamatkan & Pengangguran Terbuka & Angkatan Kerja & TPT (\%) \\
\hline 1 & SD & 7.906 & 121.011 & 6,53 \\
\hline 2 & SMP & 10.063 & 140.434 & 7,16 \\
\hline \multirow{3}{*}{3} & (SMA/K) & & & \\
\hline & SMA & 12.879 & 200.864 & 6,41 \\
\hline & SMK & 28.233 & 193.639 & 14,5 \\
\hline 4 & DIPLOMA & 1.332 & 33.693 & 3,95 \\
\hline 5 & UNIVERSITAS & 4.797 & 106.791 & 4,49 \\
\hline
\end{tabular}

Angka tingkat pengangguran terbuka di Kota Semarang bisa dikatakan cukup tinggi. Tingginya angka tersebut menandakan bahwa tingkat keterserapan tenaga kerja di sana cukup rendah. Hal ini ditunjukkan oleh data yang didapat dari Survei Angkatan Kerja Nasional (SAKERNAS) BPS di Jawa Tengah.

Berdasarkan tabel di atas terlihat bahwa tingkat pengangguran dari segala jenjang pendidikan masih tergolong tinggi di Kota Semarang. Tingkat pengangguran terbuka pada SMK tergolong yang tertinggi dari jenjang pendidikan lainnya sebesar 28.233 dari total angkatan kerja yang tersedia yaitu sebesar 193.639 atau sekitar $14,5 \%$.

Masalah pengangguran seharusnya tidak terjadi pada lulusan SMK. Sekolah menengah kejuruan menekankan pada persiapan anak didik untuk memasuki dunia kerja dengan berbekal keterampilan yang didapatkan dari proses pembelajaran praktik. Proses pembelajaran di SMK, siswa mendapatkan pengetahuan di sekolah dan pengetahuan untuk melaksanakan Praktik Kerja Industri (Prakerin). Tujuan prakerin sangatlah penting karena siswa mendapatkan pengalaman langsung dalam dunia kerja. Senada dengan apa yang dikemukakan oleh Anwar (2006) bahwa sasaran utama prakerin adalah mengoptimalkan hasil pembelajaran dan menghasilkan lulusan yang memiliki keterampilan profesional dan sesuai dengan tuntutan lapangan kerja. Pada pelaksanaan prakerin siswa tidak lagi belajar di sekolah melainkan mengaplikasikan ilmu dan prestasi yang didapat dari sekolah untuk dipraktikan langsung pada DUDI sehingga terdapat sinkronisasi atau link and match antara kompetensi yang harus dipenuhi siswa dengan penguasaan keahlian yang diperoleh dalam DUDI. Prakerin sebagai bentuk pembelajaran SMK di luar pembelajaran yeng terjadi di dalam sekolah yang membekali siswa berupa ketrampilan dan pengalaman siswa dalam pekerjaan yang sebenarnya dalam DUDI sehingga pendidikan SMK akan relevan dengan keadaan dunia kerja yang nyata. Djojonegoro (2007) menegaskan yang dimaksud link and match adalah penggalian kompetensi apa saja yang dibutuhkan pasar kerja ke depan. Terjadinya link and match antara sekolah dengan DUDI membekali siswa kesiapan kerja setelah tamat.

Berdasarkan observasi dan studi pendahuluan yang dilakukan peneliti di SMK N 9 Semarang, SMK LPI, dan SMK Perintis 2901 bahwa prakerin yang dilakukan oleh siswa SMK kompetensi keahlian akuntansi tidak sesuai dengan tujuan kompetensi akuntansi. Kompetensi siswa akuntansi seharusnya adalah mengelola bukti transaksi keuangan, mengelola buku jurnal, mengelola buku besar, menyelesaikan siklus akuntansi perusahaan jasa dan dagang, justru melaksanakan kegiatan prakerin di luar kompetensi yang seharusnya dilakukan seperti memfotokopi, menjadi customer service, mengirim surat dan faksimile, memisahkan dokumen asli dan fotokopian, menerima dan melayani tamu, mencatat kartu masuk dan kartu keluar, mengangkat telepon. Hal tersebut akan 
mempengaruhi tingkat kesiapan kerja karena kompetensi yang didapatkan saat prakerin tidak sama dengan kompetensi yang dibutuhkan oleh pihak dunia industri nantinya. Stevani dan Yulhendri (2014) menyatakan bahwa apabila pelaksanaan praktik kerja industri dilaksanakan dengan baik, keterampilan siswa meningkat dan selffefficacy (kepercayaan diri) siswa tinggi, maka kesiapan siswa memasuki dunia kerja juga akan mengalami peningkatan, sehingga tercapainya tujuan pendidikan SMK yaitu menciptakan lulusan yang siap kerja.

Berdasarkan studi pendahuluan yang dilaksanakan pada beberapa siswa SMK Bisnis Manajemen kelas XII Kompetensi Akuntansi di Kota Semarang dengan cara penyebaran angket secara acak dan terwakilkan setiap akreditasi baik akreditasi A, B maupun C, dari 56 angket diperoleh bahwa 6 siswa atau 10,17\% siswa dalam kategori kesiapan kerja rendah, 36 siswa atau $61,01 \%$ siswa memiliki kesiapan kerja dalam kategori sedang, dan 28,81\% siswa dalam kategori kesiapan kerja tinggi. Dalam hal ini kesiapan kerja siswa SMK kelas XII Akuntansi se-Kota Semarang masih belum optimal.

Belum optimalnya kesiapan kerja siswa SMK bisnis manajemen kompetensi akuntansi di Kota Semarang seharusnya tidak terjadi, mengingat tujuan SMK untuk mempersiapkan peserta didik terutama untuk bekerja dalam bidang tertentu (UU No 20 Tahun 2003), sesuai kebutuhan DUDI melalui kebijakan pemerintah dalam menerapkan pembelajaran SMK melalui konsep link and match. Konsep link and match ini merubah pembelajaran yang berbasis sekolah menjadi pembelajaran berbasis ganda, dimana dalam pembelajaran di SMK dilaksanakan di dua tempat yaitu di sekolah dan di lingkungan DUDI. Pembelajaran di sekolah berupa teori dan praktik dasar kejuruan, sementara pada lingkungan DUDI pembelajaran diperoleh melalui prinsip learning by doing yaitu berupa keterampilan produktif.

Berdasarkan paparan di atas maka masalah dalam penelitian ini adalah belum adanya link and match antara sekolah dan DUDI dan belum efektifnya pelaksanaan prakerin siswa SMK bisnis manajemen kompetensi keahlian akuntansi di Kota Semarang sehingga kesiapan kerja siswa masih belum optimal. Berdaskan latar belakang di atas maka peneliti tertarik untuk melakukan penelitian dengan judul "Pengembangan Model Kerja Sama Link and Match Untuk Meningkatkan Kesiapan Kerja Bagi Lulusan SMK Kompetensi Keahlian Akuntansi di Kota Semarang."

\section{Asumsi dan keterbatasan pengembangan}

Pengembangan model kerja sama link and match ini mengacu pada asumsi bahwa pengembangan model kerja sama link and match dapat menyesuaikan kompetensi keahlian yang dimiliki siswa dengan kompetensi keahlian yang diajarkan oleh DUDI pada saat pelaksanaan prakerin, sehingga setelah pelaksanaan prakerin selesai siswa memiliki pengalaman di duinia industri sesuai dengan kompetensi yang dimiliki dan siswa memiliki kesiapan kerja yang baik.

Ada beberapa faktor yang bisa mempengaruhi terjadinya link and match antara dunia pendidikan (SMK) dengan DUDI. Pada penelitian ini faktor yang akan dibahas adalah pendidikan sistem ganda (PSG) yang diimplementasikan melalui pelaksanaan praktik kerja industri (prakerin), sedangkan untuk faktor lain diabaikan.

\section{TINJAUAN PUSTAKA}

\section{Kesiapan Kerja}

Sekolah Menengah Kejuruan (SMK) termasuk dalam pendidikan menengah yang dalam penyelenggaraannya untuk mempersiapkan siswa agar memiliki kesiapan kerja setelah tamat. Sesuai pada Undang-Undang No. 20 Tahun 2003 Tentang Sistem Pendidikan Nasional (UUSPN) pasal 15 bahwa pendidikan kejuruan merupakan pendidikan menengah yang mempersiapkan siswa terutama untuk bekerja dalam bidang tertentu. SMK lebih menekankan tujuan pembelajaran pada kebutuhan dunia kerja.

Kesiapan kerja menurut Wagner (2006: 1) 
adalah seperangkat keterampilan dan perilaku yang diperlukan untuk bekerja dalam pekerjaan apa pun bentuknya. Kesiapan kerja menurut Wagner meliputi beberapa aspek antara lain: (1) kemampuan membaca untuk informasi; (2) diterapkan matematika; (3) menulis bisnis, (4) menulis, mencari informasi; (5) kerja sama tim; (6) pengamatan; (7) mendengarkan; dan (7) teknologi terapan.

Pendidikan Sistem Ganda (PSG)

Pendidikan Sistem Ganda merupakan bentuk penyelenggaraan pendidikan keahlian profesional yang memadukan pendidikan di sekolah dan pelatihan penguasaan keahlian yang diperoleh melalui kegiatan praktik kerja langsung di dunia usaha dan industri. Hal senada juga diungkapkan oleh Widiastono (2004: 204205) yang menyebutkan bahwa:

Pendidikan Sistem Ganda merupakan suatu bentuk penyelenggaraan pendidikan keahlian profesional yang memadukan secara sistematik dan sinkron program pendidikan sekolah dan program penguasaan keahlian yang diperoleh melalui kegiatan bekerja langsung di dunia kerja dan terarah untuk mencapai tingkat keahlian profesional tertentu tertentu.

Dalam implementasinya perubahan paradigma SMK, PSG diwujudkan dalam suatu model prakerin. Pengertian prakerin menurut Direktorat Pembinaan Sekolah Menengah Kejuruan tahun 2008 praktik kerja industri yang disingkat dengan "prakerin" merupakan bagian dari program pembelajaran yang harus dilaksanakan oleh setiap peserta didik di dunia kerja, sebagai wujud nyata dari pelaksanaan sistem pendidikan di SMK yaitu pendidikan sistem ganda (PSG).

Hamalik (2001: 91) menyatakan bahwa prakerin merupakan suatu tahap persiapan profesional di mana seorang siswa yang hampir menyelesaikan studi secara formal bekerja di lapangan dengan supervisi seorang administrator yang kompeten dalam jangka waktu tertentu, yang bertujuan untuk mengembangkan kemampuan melaksanakan tanggung jawab dalam bidangnya.

\section{Konsep dan Pengertian Link and Match}

Link and match adalah kebijakan Departemen Pendidikan dan Kebudayaan Republik Indonesia yang dikembangkan untuk meningkatkan relevansi SMK, yaitu relevansi dengan kebutuhan pembangunan umumnya dan keutuhan dunia kerja, dunia usaha serta dunia industri khususnya. Maksud keterkaitan (link) dan kesesuaian (match) adalah bahwa kompetensi lulusan dari dunia pendidikan dapat diterima dan cocok dengan kebutuhan dunia kerja.

Perspektif link menunjukkan proses, yang berarti bahwa proses pendidikan selayaknya sesuai dengan kebutuhan pembangunan, sehingga hasilnya pun cocok (match) dengan kebutuhan tersebut, baik dari segi jumlah, mutu, jenis, kualifikasi maupun dari segi waktunya. Perspektif pendidikan sebagai wahana untuk menunjang pembangunan dalam berbagai sektor dan sub sektor ada beberapa faktor yang memperkuat perlunya usaha kearah lebih menciptakan link and match antara pendidikan dan pembangunan, khususnya dengan dunia kerja.

Penerapan kebijakan link and match bertujuan untuk meningkatkan relevansi pendidikan dengan kebutuhan lapangan kerja. Hal ini sejalan sebagai usaha untuk mencari titik temu antara dunia pendidikan sebagai produsen dan DUDI sebagai konsumen. Menurut Sanjaya (2009), tujuan gerakan link and match adalah untuk mendekatkan pemasok (supplier) dengan mutu sumber daya manusia, terutama yang berhubungan dengan kualitas ketenagakerjaan. Untuk menciptakan link and match antara pendidikan dan dunia kerja diperlukan usahausaha secara resiprokal antara kedua belah pihak. Pendidikan dan dunia kerja serta masyarakat perlu melakukan dialog untuk mengidentifikasi kebutuhan masyarakat terhadap pendidikan dan menentukan langkah-langkah untuk memenuhi kebutuhan itu. 


\section{Keterkaitan Antara Kesiapan Kerja, PSG dan Link and Match}

Kesiapan kerja adalah kondisi yang menunjukkan adanya keserasian antara kematangan fisik, mental serta pengalaman bekerja, sehingga individu mempunyai kemampuan untuk melaksanakan suatu kegiatan tertentu dalam hubungan dengan pekerjaan (Zuniarti, 2013: 412). Seorang siswa dikatakan mempunyai kesiapan kerja apabila siswa tersebut memiliki kemampuan yang mencakup aspek sikap, pengetahuan dan keterampilan sesuai dengan bidangnya. Salah satu upaya yang dilakukan untuk melatih dan meningkatkan kesiapan kerja pada siswa SMK adalah dengan dilakukannya prakerin. Prakerin adalah kegiatan pendidikan, pelatihan, dan pembelajaran yang dilaksanakan di dunia usaha atau dunia industri secara langsung yang relevan dengan kompetensi (kemampuan) siswa sesuai bidangnya masing-masing. Prakerin merupakan wujud nyata dari pelaksanaan pendidikan di SMK yaitu pendidikan sistem ganda (PSG).

Pendidikan Sistem Ganda merupakan prinsip yang digunakan dalam kebijakan link and match yang dilaksanakan untuk meningkatkan mutu dan relevansi SMK dilakukan dengan peningkatan keterkaitan dan keterpaduan (link and match). Link and match mengacu pada keterkaitan (link) dan kesesuaian (match) antara dunia pendidikan dan DUDI (Djojonegoro 2007: 1; dan Judissuseno, 2008: 14) Maksudnya bahwa kompetensi lulusan dari dunia pendidikan dapat diterima dan cocok dengan kebutuhan dunia kerja.

Berdasarkan beberapa penjelasan di atas dapat dilihat bahwa terdapat hubungan saling keterkaitan antara kesiapan kerja, PSG dan link and match. Sehingga dapat dirumuskan bahwa salah satu cara yang dilakukan SMK untuk melatih dan meningkatkan kesiapan kerja siswa adalah melalui prakerin, sedangkan prakerin itu sendiri adalah wujud nyata dalam pelaksanaan PSG, dan PSG merupakan prinsip yang dipakai dalam kebijakan link and match.

\section{Sekolah Menengah Kejuruan (SMK)}

Menurut Penjelasan atas Undang-Undang RI No. 20 Tahun 2003 Tentang Sistem Pendidikan Nasional Pasal 15, pendidikan kejuruan merupakan pendidikan menengah yang mempersiapkan peserta didik terutama untuk bekerja dalam bidang tertentu. Pengertian mengenai SMK terdapat pada Peraturan Pemerintah No. 66 Tahun 2010 pasal 1 ayat 15 yang menyatakan bahwa Sekolah Menengah Kejuruan yang selanjutnya disingkat SMK adalah salah satu bentuk satuan pendidikan formal yang menyelenggarakan pendidikan kejuruan pada jenjang Pendidikan Menengah sebagai lanjutan dari SMP, MTs, atau bentuk lain yang sederajat atau lanjutan dari hasil belajar yang diakui sama atau setara SMP atau MTs.

\section{Keahlian Akuntansi}

Akuntansi adalah suatu kegiatan jasa, fungsinya adalah menyediakan data kuantitatif, terutama yang mempunyai sifat keuangan, dari kesatuan usaha ekonomi yang dapat digunakan dalam pengambilan keputusan ekonomi dalam memilih alternatif-alternatif dari suatu keadaan (Baridwan, 2008: 1), Menurut Charles T. Horngren, dan Walter T. Harrison (Horngren Harrison, 2007: 4) menyatakan bahwa akuntansi adalah sistem informasi yang mengukur aktivitas bisnis, memproses data menjadi laporan, dan mengkomunikasikan hasilnya kepada para pengambil keputusan. Tujuan akuntansi untuk menyiapkan suatu laporan keuangan yang akurat agar dapat dimanfaatkan oleh para manajer, pengambil kebijakan, dan pihak berkepentingan lainnya, seperti pemegang saham, kreditur, atau pemilik, sedangkan fungsi daripada akuntansi itu sendiri adalah sebagai informasi keuangan suatu organisasi.

\section{Model Konseptual}

Model adalah suatu cara untuk mengorganisasi kumpulan pengetahuan yang kompleks seperti konsep yang berhubungan dengan perilaku manusia. Menurut Ming-Ying 
Yang, Mantai You, dan Fei-Chuan Chen (2005) model adalah suatu deskriptif naratif untuk menggambarkan prosedur atau langkah-langkah untuk mencapai suatu tujuan khusus, dan langkah-langkah tersebut dapat dipergunakan untuk mengukur keberhasilan/kegagalan dalam mencapai tujuan.

Model konseptual merupakan konstruksi verbal atau visual yang membantu untuk membedakan antara apa yang penting dan apa yang tidak. Sebuah model menawarkan kerangka kerja yang menggambarkan (secara logis) hubungan kausal antara faktor-faktor yang berkaitan. Model konseptual menciptakan realitas dalam arti pemahaman kolektif. Karena model konseptual didasarkan pada bahasa yang berasal dari pengertian teoritis.

\section{METODE PENELITIAN}

Jenis penelitian ini adalah Research and Development (R\&D). Lokasi penelitian ini dilakukan di SMK Negeri 9 Semarang, SMK LPI, dan SMK Perintis 29-01 Jurusan Bisnis Manajemen Kompetensi Keahlian Akuntansi dan Dunia Usaha Dunia Industri (DUDI) pasangan. Penetapan informan sebagai sumber data menggunakan teknik purposive sampling. Pengumpulan data menggunakan teknik wawancara mendalam, observasi, dokumentasi dan angket. Penelitian ini menggunakan metode kualitatif dan kuantitatif. Metode kualitatif dilakukan dengan wawancara mendalam, observasi dan dokumentasi untuk mengembangkan model kerja sama link and match untuk meningkatkan kesiapan kerja, sedangkan metode kuantitatif dilakukan dengan pengisian angket untuk analisis kebutuhan penelitian. Keabsahan data diperoleh melalui credibility, transferability, dependability, dan confirmatory. Analisi data kualitatif: reduksi data, paparan data, dan penarikan kesimpulan data dan verifikasi, kuantitatif: validitas dan reliabilitas.

\section{HASIL PENELITIAN DAN PEMBAHASAN Tahap Pendahuluan}

Penelitian ini dimulai pada tahap pendahuluan yaitu dengan melakukan observasi awal lapangan untuk menggali objek penelitian. Pada tahap ini peneliti melakukan observasi awal dan analisis kebutuhan mengenai kesiapan kerja siswa SMK kompetensi keahlian akuntansi di Kota Semarang dengan cara penyebaran angket secara acak dan terwakilkan setiap akreditasi baik akreditasi A, B, maupun $\mathrm{C}$ dan kegiatan siswa kompetensi keahlian akuntansi pada saat praktik kerja industri. Setelah masalah dalam penelitian diketahui maka langkah selanjutnya adalah membuat daftar pertanyaan digunakan untuk menggali informasi mengenai pelaksanaan link and match yang selama ini dilakukan di sekolah.

Langkah selanjutnya yang dilakukan adalah mengadakan orientasi lapangan dengan objek penelitian, mengumpulkan data dan menggali informasi dari informan melalui wawancara, observasi dan pengumpulan dokumen. Berdasarkan hasil wawancara diperoleh informasi mengenai pelaksanaan link and match yang selama ini dilakukan. Langkah selanjutnya adalah menginterpretasikan dan menganalisis dengan sejumlah data yang diperoleh dan menelaah data dengan bangunan konsep berdasarkan studi pustaka dan penelitian yang sudah ada.

Berdasarkan langkah-langkah di atas, maka dalam tahap pendahuluan ini akan dijelaskan mengenai data yang telah diinterpretasikan dan dianalisis. Hasil penelitian tersebut dijelaskan sebagai berikut:

a. Kompetensi Lulusan Harapan DUDI

D Akuntansi: melakukan kegiatan pembukuan, mengerjakan akuntansi komputer, menyusun laporan keuangan, dan tambahan lainnya adalah mengetik manual baik mesin ketik manual maupun mesin ketik elektronik.

- Tata Boga: mengolah dan menyajikan makanan kontinental yang terdiri dari 
makanan pembuka, makanan utama dan makanan penutup, melayani makan dan minum, dan mengorganisir operasi makanan.

D Teknik Komputer Jaringan: merakit Personal Computer (PC), melakukan instalasi sistem operasi dasar, mendiagnosis permasalahan pengoperasian PC, dan melakukan perbaikan/setting ulang sistem PC.

D Administrasi Perkantoran: bidang peralatan, kearsipan, komunikasi, proses surat menyurat, pembukuan dana kas kecil, perjalanan bisnis, dan tambahannya adalah menerima tamu.

> Pemasaran/Penjualan: perencanaan penataan produk, melayani pelanggan, administrasi penjualan, dan mempersiapkan dan mengoperasionalkan peralatan.

D Rekayasa Perangkat Lunak: menginstal software, mengoprasikan sistem operasi, melakukan pengkodean program, merancang desain dan perencanaan software, dan pengoprasian bahasa pemrograman berbasis web dan internet.

b. Kompetensi Lulusan SMK

SMK Negeri 9 Semarang mempunyai 4 Program Keahlian, yaitu: Administrasi Perkantoran, Akuntansi, Pemasaran/ Penjualan dan Rekayasa Perangkat Lunak. SMK LPI memiliki 2 program studi yaitu akuntansi dan rekayasa perangkat lunak. SMK Perintis 29-01 memiliki 3 program studi yaitu Akuntansi, Tata Boga dan Teknik Komputer Jaringan.

D Akuntansi

Tujuan: tenaga akuntansi yang memiliki pengetahuan dan nilai serta sikap yang terintegrasi dan berkecakapan kerja bidang akuntansi dengan menerapkan kewiraswastaan serta mampu mengadaptasi perkembangan masyarakat yang sesuai dengan kemajuan ilmu dan teknologi serta dapat memenuhi tuntutan dunia kerja masa sekarang dan masa datang. Kompetensi lulusan: melakukan kegiatan pembukuan, mengerjakan akuntansi komputer, menyusun laporan keuangan, dan tambahan lainnya adalah mengetik manual baik mesin ketik manual maupun mesin ketik elektronik. Bidang pekerjaan: Pemegang buku, Kasir/ teller, Juru penggajian, Operator mesin hitung, Operator komputer, Petugas administrasi gudang, Menyusun laporan keuangan.

$>$ Tata Boga

Tujuan: Menyiapkan tenaga kerja profesional tingkat menengah untuk kebutuhan di bidang jasa boga (restoran, rumah makan, perhotelan, perusahaan dan jasa yang bergerak di bidang makanan dan minuman). Kompetensi lulusan: mengolah dan menyajikan makanan kontinental yang terdiri dari makanan pembuka, makanan utama dan makanan penutup, melayani makan dan minum, dan mengorganisir operasi makanan. Bidang pekerjaan: Bartender, Restaurant/Bar Manager, Wirausaha Boga.

D Teknik Komputer Jaringan

Tujuan: Menghasilkan lulusan tenaga komputer untukmengisilowongan kerja di bidang Teknik Komputer Jaringan yang terampil, disiplin, tanggung jawab, dan berakhlak mulia yang sesuai dengan tuntutan dunia usaha/dunia industri. Kompetensi lulusan: merakit Personal Computer (PC), melakukan instalasi sistem operasi dasar, mendiagnosis permasalahan pengoperasian PC, dan melakukan perbaikan/setting ulang sistem PC. Bidang pekerjaan: Teknisi Jaringan dan Komputer.

D Administrasi Perkantoran Tujuan: Tenaga pelaksana yang me- 
miliki pengetahuan ketrampilan nilai dan sikap sebagai manusia yang bertanggung jawab dan mencintai profesi pekerjaannya. Kompetensi lulusan: bidang peralatan, kearsipan, komunikasi, proses surat menyurat, pembukuan dana kas kecil, perjalanan bisnis, dan tambahannya adalah menerima tamu. Bidang pekerjaan: Juru tata usaha kantor, Sekretaris muda, Juru TIK, Resepsionis.

$>$ Pemasaran/Penjualan

Tujuan: Menyiapakan tenaga pelaksana yang profesional dalam bidang bisnis (dunia usaha) serta mengembangkan sikap kewirausahaan. Kompetnsi lulusan: perencanaan penataan produk, melayani pelanggan, administrasi penjualan, dan mempersiapkan dan mengoprasionalkan peralatan. Bidang pekerjaan: Pramuniaga, Tenaga pemasaran, tenaga pengelola gudang, Kasir, Tenaga administrasi penjualan dan pembelian.

> Rekayasa Perangkat Lunak

Tujuan: Menghasilkan tamatan yang berkualitas dan mampu bersaing di pasar tenaga kerja baik nasional maupun internasional di bidang teknologi informatika, rekayasa perangkat lunak (Software Enginering). Kompetensi Lulusan: menginstal software, mengoprasikan sistem operasi, melakukan pengkodean program, merancang desain dan perencanaan software, dan pengoperasian bahasa pemrograman berbasis web dan internet. Bidang pekerjaan: Operator komputer, Pelaksana IT, Programer komputer tingkat dasar.

c. Pelaksanaan Link and Match yang selama ini dilakukan oleh SMK dan DUDI pasangan

Link and match dilakukan dengan pembelajaran yang dilakukan di DUDI yang disebut praktik kerja industri atau prakerin.
Secara garis besar prakerin terdiri dari 3 tahap yaitu, persiapan, pelaksanaan dan evaluasi. Pada pembahasan kali ini akan dipaparkan sebagai berikut: pemahaman, persiapan, pelaksanaan, pengendalian, dan faktor pendukung dan penghambat.

$\checkmark$ Pemahaman

Secara umum pihak sekolah mengerti dan memahami konsep pendidikan sistem ganda dari Dinas Pendidikan Menengah Kejuruan Kanwil Pemerintah Kota Semarang. Kepala sekolah menyampaikannya melalui rapat dan sosialisasi kepada guru. Guru memberitahukan kepada siswa pada saat Masa Orientasi Sekolah (MOS) yaitu saat pertama kali masuk sekolah.

$\checkmark$ Persiapan

Persiapan dilakukan dengan membentuk panitia kerja, pendaftaran DUDI pasangan, pemilihan guru pembimbing, penyusunan program bersama dan penyiapan siswa.

D Pelaksanaan

Pelaksanaan prakerin dilaksanakan dalam waktu kurang lebih selama 3 bulan. Sistem pembelajaran yang dipakai adalah block release untuk menjaga keseimbangan praktik Pola ini merupakan kesepakatan bersama antara pihak sekolah dengan DUDI. Setelah selesai pelaksanaan akan diadakan ujian praktik kompetensi yang dilakukan oleh assesor baik eksternal maupun internal.

$\checkmark$ Pengendalian

Aspek pengendalian dalam pelaksanaan prakerin meliputi: program pendidikan dan pelatihan kejuruan, sumber daya manusia, fasilitas pendidikan, manajemen pendidikan, siswa, biaya, dan institusi pasangan.

- Faktor pendukung

Faktor pendukung pelaksanaan prakerin adalah ketersediaan DUDI 
menerima siswa praktik, sedangkan faktor penghambatnya adalah masalah ketidakdisiplinan siswa dalam hal ini kehadiran.

Sedangkan pelaksanaan link and match pada DUDI pasangan terdiri dari:

D Pemahaman

Pemahaman DUDI dalam memahami konsep pendidikan sistem ganda masih bisa dibilang rendah, dalam artian pihak DUDI menyamakan siswa prakerin dengan praktikan lainnya, hanya saja dengan sebutan yang berbeda.

D Persiapan

DUDI akan mempersiapkan diri untuk memilih ruangan siswa praktik, administrasi, pemilihan instruktur, dan kriteria siswa praktik. DUDI memiliki peran sebagai sumber informasi yang memberikan verifikasi dan validasi program dalam penyusunan program bersama.

D Pelaksanaan

Pelaksanaan PSG dalam link and match akan melibatkan proses kerja sama antara sekolah dan DUDI dalam cakupan yang cukup luas, kerja sama tersebut terjalin dari mulai tahap persiapan, penyusunan program bersama, pelaksanaan, pelatihan sampai pada tahap evaluasi. Pada tahap pelaksanaan DUDI tidak hanya dijadikan sebagai tempat praktik, tetapi juga menyiapkan instruktur lapangan.

$\triangle$ Evaluasi

Pada tahap terakhir dalam pelaksanaan prakerin, DUDI dan sekolah bekerja sama dalam pelaksanaan evaluasi yang memberikan penilaian siswa praktikan sebagai asesor eksternal. Selain itu, DUDI juga memberikan sertifikat sebagai tanda pengalaman kerja bagi siswa yang telah melaksanakan pelatihan industri.

Faktor Pendukung dan Penghambat
Faktor pendukung pelaksanaan prakerin dari DUDI pasangan diantaranya adalah terbukanya sikap DUDI dalam menerima siswa untuk melakukan praktik lapangan, sedangkan faktor penghambat prakerin dari DUDI pasangan adalah masih minimnya pemahaman DUDI tentang prakerin, dan instruktur lapangan yang tersedia dari pihak DUDI yang masih minim jumlahnya.

\section{Tahap Pengembangan Model}

a. Model Awal

Berdasarkan penjelasan di atas, maka model awal skema pelaksanaan link and match di SMK dan DUDI pasangannya dapat digambarkan secara konseptual sebagai berikut: 


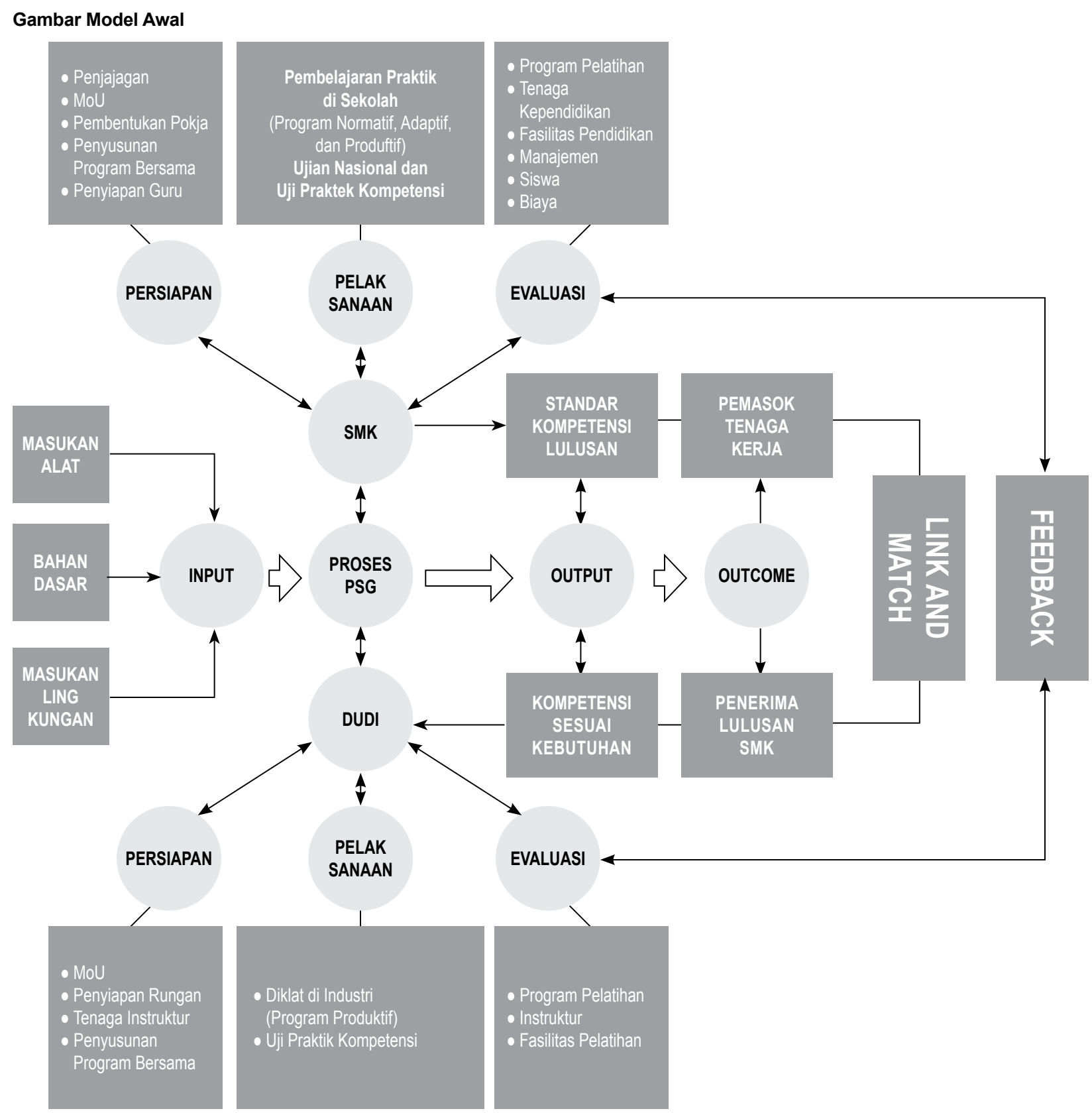

Model empirik merupakan desain model hasil observasi dan penelitian yang menghasilkan temuan. Model empirik dikembangkan berdasarkan pelaksanaan pendidikan sistem ganda yang merupakan prinsip dari kebijakan link and match yang berupa praktik kerja industri (prakerin) dimana pembelajaran dilakukan di dunia industri selama periode tertentu yang bertujuan untuk mengembangkan kemampuan melaksanakan tanggung jawab dalam bidangnya.

Pada model empirik yang dilaksanakan masih terdapat kekurangan, diantaranya pelaksanaan prakerin yang tepat seharusnya dapat memberikan pengalaman kepada siswa karena siswa harusnya bisa belajar mengaplikasikan langsung pengetahuan yang didapat di sekolah, tetapi yang terjadi apa yang diaplikasikan siswa di dunia industri tidak sesuai dengan kompetensi yang dimiliki. Hal tersebut menunjukan adanya ketidaktahuan DUDI tentang kompetensi apa yang seharusnya diberikan kepada siswa. Tercapainya suatu kompetensi lulusan yang siap kerja mengharuskan 
adanya upaya komunikasi yang baik antara sekolah dan DUDI. Sekolah harus mensosialisasikan tentang kompetensi apa yang dimiliki siswa dan kompetensi apa yang seharusnya diajarkan DUDI kepada siswa, sehingga setelah selesai pelaksanaan prakerin siswa memiliki kesiapan kerja yang baik karena telah memiliki pengalaman selama prakerin.

b. Model Hipotetik

Model hipotetik merupakan model pengembangan dari model empirik, dan merupakan model yang dikembangkan untuk mengatasi berbagai masalah yang terjadi dalam pelaksanaan link and match. Berdasarkan pada sejumlah temuan dan juga studi pendahuluan dengan teknik triangulasi data maka model hipotetik dikembangkan dengan menambahkan sejumlah komponen sebagai berikut:

Komponen sosialisasi kompetensi yang berfungsi untuk memberitahukan tentang kompetensi yang dimiliki siswa dan kompetensi apa yang seharusnya diajarkan DUDI kepada siswa, dan penambahan garis yang menghubungkan antara DUDI dan bahan dasar atau masukan lingkungan. Masukan lingkungan merupakan faktor lingkungan yang secara langsung maupun tidak langsung aspek ini akan mempengaruhi proses pembelajaran dan muaranya pada masalah mutu lulusan, sedangkan bahan dasar merupakan siswa yang akan mengikuti proses pendidikan. Garis penghubung tersebut dimaksudkan bahwa DUDI seharusnya juga berperan dalam proses seleksi penerimaan siswa dan ikut dalam memberikan masukan berupa identifikasi kompetensi. Hal ini bertujuan untuk menentukan kebutuhan kompetensi.

c. Model Akhir

Model akhir merupakan model yang telah dikembangkan untuk meminimalisir atau mengatasi masalah yang selama ini sering terjadi pada model awal dan memperjelas model hipotetik dengan menambahkan beberapa komponen, serta memperjelas komponen yang masih belum dimengerti. Perubahan pada hasil akhir meliputi hal-hal berikut ini:

1. Penambahan komponen sosialisasi kompetensi siswa

Berdasarkan hasil penelitian yang dilakukan tentang pelaksanaan prakerin yang dilakukan selama ini, diketahui bahwa pihak DUDI ternyata tidak mengetahui tentang kompetensi apa yang dimiliki siswa dan kompetensi apa yang seharusnya DUDI ajarkan kepada siswa, sehingga pada saat prakerin siswa tidak melakukan praktik sesuai dengan kompetensi yang dimiliki. Hal seperti ini terjadi pada siswa kompetensi keahlian akuntansi. Siswa kompetensi keahlian akuntansi seharusnya melakukan prakerin sesuai dengan kompetensi yang dimiliki, seperti memproses dokumen transaksi, dan menyusun laporan keuangan, tetapi yang terjadi selama ini, siswa kompetensi keahlian pada saat prakerin justru malah melakukan kegiatan yang berhubungan dengan surat menyurat, fotocopy dan penataan arsip-arsip. Penambahan komponen ini bermaksud sebagai wadah agar DUDI mengetahui kompetensi apa yang dimiliki siswa dan kompetensi apa yang seharusnya diajarkan kepada siswa.

2. Keterlibatan DUDI dalam penerimaan siswa baru

Keterlibatan DUDI dalam penerimaan siswa baru dilakukan dengan cara mengadopsi sistem perekrutan karyawan. Hal ini bertujuan agar siswa sudah terkondisi seperti pada penerimaan pegawai yang secara umum akan lebih mendorong tercapainya hasil kompetensi lulusan.

3. Adanya identifikasi kompetensi oleh 
DUDI

Identifikasi kompetensi dilakukan dengan menyusun pengembangan permodelan kompetensi sesuai standar kebutuhan, menyusun strategi pelaksanaan dengan memanfaatkan sumber metode untuk mencapai kesesuaian kompetensi. Tujuan dari penambahan komponen ini adalah untuk memberikan arahan dalam menyusun program pengembangan kurikulum, jika program dikembangkan bersama-sama antara sekolah dengan DUDI, maka akan ada kesamaan tujuan.

Model akhir link and match untuk meningkatkan kesiapan kerja digambarkan sebagai berikut:

\section{Gambar Model Akhir}

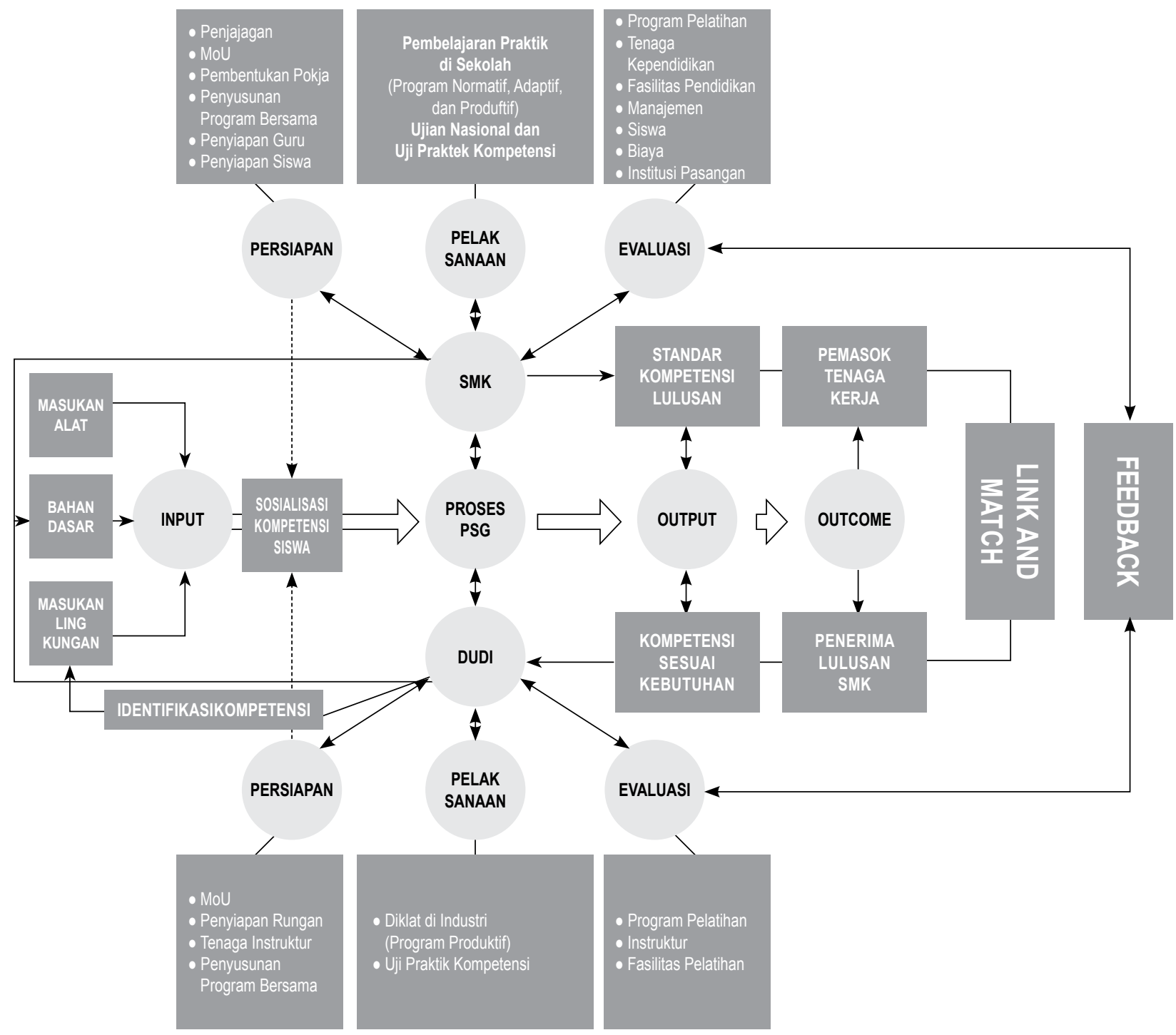


Validasi model dilakukan oleh pihak sekolah, dalam hal ini kepala sekolah dan wakil kepala sekolah, baik SMK Negeri 9 Semarang, SMK LPI, SMK Perintis 29-01 dan DUDI. Validasi model dilakukan dengan cara Forum Group Discussion (FGD) untuk menilai apakah model sudah benar-benar sesuai secara teoritis dan praktis. Validasi model didahului dengan diskusi dengan pihak sekolah. Setelah mendapat masukan dari pihak sekolah selanjutnya model direvisi sehingga menjadi bentuk model akhir kemudian dilanjutkan dengan penyerahan draf hasil akhir kepada pihak DUDI.

\section{Model Kerja Sama Link and Match yang Efektif}

Kata kunci dari link and match adalah kesesuaian kompetensi, dengan kata lain efektivitas model akan dicapai bilamana model mengantarkan standar kompetensi lulusan SMK sama dengan kompetensi harapan DUDI sehingga nantinya siswa akan memiliki kesiapan kerja. Pendidikan Sistem Ganda merupakan prinsip dalam pelaksanaan link and match, oleh karena itu perencanaan model efektif dalam model kerja sama link and match adalah mengembangkan pola pelaksanaan PSG di SMK. Kajian empirik menemukan adanya kendala-kendala dalam pelaksanaan PSG, untuk itu pengembangan model harus diupayakan untuk menghilangkan atau minimalnya mengeliminir kendala yang ada dalam PSG. Penelitian ini mengajukan perlunya penambahan unsur proses sosialisasi kepada DUDI, keterlibatan DUDI dalam penerimaan siswa baru dan identifikasi kebutuhan oleh DUDI.

\section{KESIMPULAN DAN SARAN KESIMPULAN}

1. Pengembangan model kerja sama link and match untuk meningkatkan kesiapan kerja dilakukan dengan menambahkan komponen sosialisasi kompetensi siswa, keterlibatan DUDI dalam penerimaan siswa baru dan identifikasi kompetensi kebutuhan oleh DUDI. Penambahan komponen sosialisasi kompetensi siswa bertujuan agar DUDI mengetahui kompetensi apa yang dimiliki siswa dan kompetensi apa yang harus diajarkan kepada siswa, sedangkan keterlibatan DUDI dalam penerimaan siswa baru dan identifikasi kompetensi kebutuhan oleh DUDI bertujuan untuk pengkondisian siswa seperti pada penerimaan pegawai yang akan mendorong ketercapaian kompetensi dan untuk mengidentifikasi kebutuhan kompetensi DUDI.

2. Model kerja sama link and match dikatakan efektif bilamana model model kerja sama link and match mengantarkan standar kompetensi lulusan SMK sama dengan kompetensi harapan DUDI sehingga nantinya siswa akan memiliki kesiapan kerja yang baik.

\section{SARAN}

1. Untuk menghasilkan lulusan yang siap kerja, sekolah harus menjalin komunikasi yang baik dengan DUDI tentang kompetensi yang dimiliki siswa dengan cara menyosialisasikan kepada DUDI, sehingga siswa bisa melaksanakan prakerin sesuai dengan kompetensi yang dimiliki.

2. Pelaksanaan prakerin harus lebih mengoptimalkan keterlibatan DUDI melalui penyusunan program bersama dan sosialisasi kompetensi sehingga kompetensi tujuan siswa akan tercapai.

\section{DAFTAR PUSTAKA}

Anwar. 2006. Pendidikan Kecakapan Hidup (Life Skills Education). Bandung: Cv Alfabeta.

Arif, A. dan Wibowo. 2004. Akuntansi untuk Bisnis Usaha Kecil dan Menengah. Jakarta: PT Grasindo.

Baridwan, Z. 2008. Intermediate Accounting. Yogyakarta: BPFE.

Djojonegoro, W. 1999. Pengembangan Sumber Daya Manusia: Melalui Sekolah Menengah Kejuruan (SMK). Jakarta: PT Balai Pustaka.

Horngren, Charles T. dan Walter T. Harrison. 2007. Akuntansi Jilid Satu. Edisi Tujuh. 
Jakarta: Erlangga.

Judisseno, Rimsky K. 2008. Jadilah Pribadi yang Kompeten di Tempat Kerja. Jakarta: PT Gramedia Pustaka Utama.

Peraturan Pemerintah Republik Indonesia No. 66 Tahun 2010 Tentang Pengelolaan dan Penyelenggaraan Pendidikan.

Sanjaya, W. 2009. Perencanaan dan Desain Sistem Pembelajaran. Jakarta: Kencana Prenada Media Grup.

Sugiyono. 2012. Metode Penelitian Pendidikan: Pendekatan Kuantitatif, Kualitatif, dan R\&D. Bandung: Alfabeta.

Undang-Undang Republik Indonesia No. 20 Tahun 2003 Tentang Sistem Pendidikan National. Jakarta: Departemen Pendidikan Nasional.

Widiastono, T. 2004. Pendidikan Manusia Indonesia. Jakarta: Kompas.

Yang, Ming-Ying, Manlai You, dan Fei-Chuan Chen. 2005. Competencies and qualification for industrial design job: implication for design practice, education and student career guidance: Elsevier Ltd. pp: 155-189. 